\title{
parents' philosophical community: when parents go to school!
}

\author{
maria papathanasiou 1 \\ federico ii naples university, italy \\ orcid id: https://orcid.org/0000-0001-9356-5200
}

\begin{abstract}
Research seems to be explicit on children's benefit from parental participation in their schooling. The ways in which parents can be involved, though (or however), are not yet apparent. A variety of educational approaches and programs are being tested globally in order to enhance school's collaboration with families. Through Action Research (AR), the effect of an initiative parental-school engagement has been explored in a kindergarten school in Athens during the 2014-15 and 2015-16 school years. The successful engagement of philosophical practices for the students in previous years exposed the need for adopting the specific tool of Philosophy for Children for the community of parents. Carefully selected stories have been used as a stimulus for raising philosophical questions that were analyzed in depth by parents and teachers. The creation of a philosophical community of inquiry with parents within the school revealed a new horizon of communication and cooperation while also raising respect and empathy among all participants. This research exhibits that when formulating communities of philosophical inquiry with children and adults alike, and within the same environment, meaningful dialogue can be revealed and reinforced among all parts of the school's community triangle (students, teachers, parents). As a result, an alternative educational approach that strengthens school-family alliance has been unveiled.
\end{abstract}

keywords: school-family collaboration, philosophical community, dialogue.

\section{comunidade filosófica de responsáveis: quando pais e mães vão à escola!}

\section{resumo}

As pesquisas parecem ser explícitas no que toca o benefício da participação dos/das responsáveis na escolarização das crianças. As maneiras pelas quais os pais e mães podem ser envolvidos/as, entretanto, ainda não são evidentes. Uma variedade de abordagens e programas vêm sido testados de forma global com o objetivo de aumentar a colaboração da escola para com as famílias. Através de Pesquisa-Ação, o efeito de uma iniciativa de comprometimento entre pais e mães e a escola foi explorado em uma escola de educação infantil em Atenas durante os anos escolares de 2014-15 e 2015-16. O bem-sucedido compromisso com práticas filosóficas para os/as estudantes em anos passados demonstrou a necessidade de adotar a ferramenta específica da Filosofia para Crianças para a comunidade de pais, mães e responsáveis. Histórias cuidadosamente selecionadas foram utilizadas como

1 E-mail: mpapsal@gmail.com 
estímulo para levantar questões filosóficas, que foram analisadas profundamente por responsáveis e professores/as. A criação de uma comunidade de investigação filosófica com os/as responsáveis na escola revelou um novo horizonte de comunicação e cooperação ao mesmo tempo também aumentando o respeito e a empatia entre todos os participantes. Essa pesquisa mostra que quando se formulam comunidades de investigação filosófica com crianças e adultos em igualdade e dentro do mesmo ambiente, diálogos significativos podem emergir e se fortalecer em todas as partes do triângulo comunitário da escola (alunos/as, professores/as, responsáveis). Como resultado, uma abordagem educacional alternativa que fortalece os laços escola-família pôde ser revelada.

palavras-chave: colaboração escola-família, comunidade filosófica, diálogo.

\section{comunidad filosófica de representantes: ¡cuando los padres y las madres van a la escuela!}

\section{resumen}

La investigación muestra el beneficio que trae para los niños y niñas la participación de la familia en su escolarización. Sin embargo, las formas en que la familia puede participar todavía no son evidentes. Una variedad de estrategias y programas educativos están siendo probadas globalmente para mejorar la colaboración entre la escuela y la familia. A través de Action Research, se exploró la efectividad de una iniciativa de cooperación con las familias en una escuela Infantil en Atenas, durante los años escolares 2014-15 y 2015-16. La participación exitosa en las prácticas filosóficas de los estudiantes en años anteriores expuso la necesidad de adoptar la herramienta específica de Filosofía para Niños (y Niñas) en la comunidad de padres, madres y representantes. Las historias, cuidadosamente seleccionadas, se han utilizado como un estímulo para plantear cuestiones filosóficas que fueron analizadas a profundidad por los padres, madres, maestros y maestras. La creación de una comunidad de investigación filosófica con las familias dentro de la escuela, revela un nuevo horizonte de comunicación y cooperación, al tiempo que genera respeto y empatía entre todos los y las participantes. Esta investigación muestra que la construcción de comunidades de investigación filosófica con niños, niñas y adultos de la misma manera, y dentro del mismo entorno, refleja y fortalece el diálogo entre todas las partes del triángulo de la comunidad escolar (estudiantes, maestros-maestras y padres-madres-representantes). Como resultado, se ha revelado un enfoque educativo alternativo que fortalece la alianza entre la escuela y la familia.

palabras clave: colaboración escuela-familia; comunidad filosófica; diálogo. 
parents' philosophical community: when parents go to school!

\section{introduction}

International research (Epstein, 1985; Henderson, 1987) points out how reinforced parental collaboration within the school community seems to have positive effects on their children's academic success (Aronson, 1996), whilst improving their attitude and school performance (Bradley, Caldwell, \& Rock, 1988) as well. The research agenda shows that the ways parents may enhance the educational experiences of their children is more prominent through cooperation processes within the school community.

Epstein's framework seems, by research outcomes, to be one of the most promising interventions that promote Parents' involvement in school (Epstein, 1982, 1987). It incorporates 6 different types of involvement that include: guidance/training of parents, communication and information about the educational program, voluntary participation of parents in school's activities, support of children's learning at home, participation in decision-making and cooperation with local community institutions aiming at the support of school programs (Keyes, 2002). The particular cooperation model has proved to be effective in student's achievement (Epstein et al, 2002, Fan \& Chen, 2001), attendance (Fan \& Chen, 2001), and emotional well-being (Epstein, 2005) and has been used by the US National Parent Teacher Association (PTA) to provide standards for parent/teacher involvement programs (National PTA, 1997). However, in order to enhance active and reflective engagement of parents into school's educational strategies and practices, it should be complemented with an educational tool aimed at enhancing the capacity of parents to communicate, cooperate, and reflect with the school community and to be actively engaged in essential dialogue with their children.

A training program for parents that follows new standards of cooperation has been explored in this research. More specifically, this AR suggests a new learning 
opportunity that offers parents a variety of skills to deal with their children's education. It raises interest in an innovative educational formation that provides parents the means to engage deeper into their child's life, and to better understand themselves. In addition, it appears to strengthen the already burdened teachers, who, unfortunately, are required to meet the demands of the modern economic and political system every day rather than the actual educational needs of their students. The specific pedagogical proposition includes, but is not limited to, diverse individuals (i.e. in ideas, beliefs, socio-economic backgrounds), in a multicultural environment, that are given the chance to voice their ideas in a democratic, empathic and respectful manner and co-construct a community that promotes trust and wellbeing, while establishing a Community of Philosophical Inquiry.

Through this differentiated model of collaboration with parents, both philosophical inquiry and a meaningful dialogue were exploited as a means for shaping an appropriate family environment towards a positive impact on the social and emotional development of the children, whilst amplifying their academic performance. The main emphasis of the aforementioned type of parents' engagement is grounded on the development of reasoning, reflection and philosophical quest, in the sense of the revival of grassroots philosophy outside of Academia (Lipman, 1991). It has actually been inspired by Lipman's educational model known and practiced as Philosophy for Children, P4C (2003). Similarly to that model, stories embedded with philosophical concepts have also been read, aiming at provoking philosophical inquiries from the parents, as practiced with the children. Problematizing parents and children in respective ways through storytelling has been an experimental strategy used thoroughly in the project to stimulate philosophical quests. The stories that were applied were children's stories that have also been read previously in the classroom to the students prompting a philosophical discussion. These carefully selected stories were aiming to stimulate philosophical concepts such as Friendship, Love, Peace, Children's Rights, Truth, Justice etc. They served as triggers for reflection and 
philosophical inquiry in both age groups (students and parents) almost likewise, as though it has been argued (Neile, 2009), that "stories remind us that even if we do not know the answers. it is the questions that are paramount". The structure of the sessions with the parents, even though well organized and inspired by Lipman and Sharp's theory, were not following the exact pattern. However, stories worked as stimuli for philosophical questions that were further discussed within the sessions.

Conclusively, the specific project that is presented in this article combined Epstein's cooperation model whilst attempting to form a community of inquiry with parents. The model that was added has been inspired by Lipman's Community of Philosophical Inquiry methodology. During the referred school years (2014-2016), two groups (Experimental \& Control) were determined for this research. Epstein's cooperation model, which had been already adopted from the previous years at the school with positive results, was implemented in both groups. However, the parents' philosophical community venture has been applied only to the Experimental Groups. The results and conclusions of the project are unfolded and analyzed in another section.

\section{theoretical background}

School - Family Cooperation

Parents are widely considered reference persons and paradigms for their children. They model and share values and attitudes towards life through interfamily relationships as specified in the theory of Social Learning (Bandura, 1977). The Bronfenbrenner Ecological Model Theory (1979) further supports the aforementioned influence. According to this theory, the immediate environment-microsystem (i.e. home, school), the interaction-mesosystem of the members of the microsystem (i.e. parents, teachers, students), the immediate social environmental-exosystem, the cultural environment-macrosystem (i.e. economy, politics, culture) and the synchronization of various chronosystemic events during a child's life, influence and 
shape its evolution. Accordingly, school and family are treated as part of the same system whose interaction is considered both desirable and self-evident.

The influence of parents on their child's life is further analyzed in recent research and theories on parenting and its importance in a child's social, emotional, and cultural development (Anfara, Jr. \& Mertens, 2008). According to international literature (Comer, J. 2005, Raffaelle, L. \& Knoff, M. 1999), the most important factors that influence school performance and children's learning opportunities are the educational level and habits of the parents (Becker \& Epstein, 1982, Aronson, 1996), the size of the family, and its socio-emotional environment in which children are engaged and acquire essential skills in school readiness and preparation. According to the above mentioned, the social and cultural background, the diverse personal experiences and events in parents' lives, effect both the learning and all-around development of their children. Respectively, Moles (1993) argued that the reduced skills and awareness of interaction and communication between both families and educators create barriers to complementary relationships.

Additionally, it is argued that highly educated parents usually have better communication skills and methods that are more effective in emphasizing the significance of educational success to their children (Steinberg \& Silk, 2002). Furthermore, high socio-economic status (SES) parents can obtain educational information from professional consultants beyond schools. This information can be useful for parents in supporting their child's education through daily conversation. In short, because of differential resources and skills between higher SES and lower SES parents, even an equal amount of communication with the child may vary substantially in its impact on children's educational outcomes. Conclusively, this difference appears to, on one hand, have an impact on the attitude of the educators towards parents, and on the other hand, on parents' engagement with the school community. Indicatively, educators often hold a cautious or even distant attitude towards the families of their students, and many parents are reluctant, indifferent, or 
even aggressive towards their teachers and supervisors (Chavkin, \& Williams, 1987). Nonetheless, in many cases when parents are non-participative in their children's school-life, especially if they belong to a minority, teachers take it as indifference (Carasquillo \& London 1993).

Based on a sound analysis of the scientific literature, we recognize other factors that play an indisputable role in empowering the family-school relationship. One of them, according to Raffaelle, L. \& Knoff, M. (1999), is the organization and system that requires, among other things, family and school cooperation. These authors argue that the effectiveness of such cooperation should be based mainly on prevention rather than on reaction. That is, educators in the pedagogical process should refer to all families and not only to those whose children are facing school or learning difficulties. This means that the school should acknowledge and value the important contribution of parents, regardless of their educational or/and socioeconomic background. Moreover, and according to Comer (2005), children need emotional support in order to learn. This support seems to develop efficiently when the family and school educators work together for the benefit of children. In addition, Bali, Demo \& Wedman (1998), and Griffith (1996) emphasize the improvement of children's behavior, as well as parental and pedagogical relationships, which arise because of parental participation in developing school curricula. In other research, such as that of Epstein (2001), the importance of parents' participation in the education of their children from preschool to adolescence, as well as its relationship to the positive socio-emotional development of the children is documented, while also highlighting the positive impact on their school performance. Conclusively, research recognizes the beneficial role of an enhanced family-school relationship for the school community and, more importantly, for the students.

models of cooperation 
Various models of cooperation are presented in the relevant bibliography. Each of these bring out a different perspective on how the relationship between family and school is perceived by emphasizing the specific characteristics of this relationship. We briefly mention some of them: a) the Model of the parents' positions, which refers to a sociological perspective of the school-family relationship by emphasizing the role of parents in relation to the education of their child (Vincent, 2000), b) the Model of parental roles in education introduced by Greenwood and Hickman (1991) and which attempts an approach to the parents' role as they interact with teachers and in conjunction with the boundaries set by the school for parental participation in their children's education and c) the evolutionary Model of the family and school relationship of Martin, Ranson and Tall (1997), that emerged after a largescale survey to inspect the quality of education provided in England.

Finally, there are also d) the Model of overlapping spheres of the family and school, (Epstein, 2001) and e) the Model of influences and consequences of parental involvement in the school of Eccles and Harold (1996), which are two approaches that reflect elements of Ecological Theory (Bronfenbrenner, 1979), according to Penteri (2012). All the models mentioned above clearly identified the roles, actions, and relationships in every phase of interaction of the family within the school community, despite the existence of differentiations. However, the latter two develop a systemic vision of the relationship between the school and the families while at the same time emphasize the processes, perceptions, practices, and characteristics of the three intermediary organizations: parents, teachers, and pupils (Poulou and Matsaggoyras, 2008).

adults' learning, community and philosophy

As Brookfield (1983) points out, adults' learning aims to transform society by enhancing knowledge and skill. The relationship, therefore, between adult education and society is narrow. One of the approaches to adult education is that of community 
education, which aims at two interdependent levels. The first level is that of personal knowledge and skill acquisition whilst the second is that of progress and community empowerment (Connolly, 2005). Therefore, adults' learning within a community education system requires individuals to be consciously aware of the intention of social change, whilst preconditioning the readiness to renegotiate some of the traditional roles of the educational process.

A philosophical community is a phenomenon that comes from antiquity but continues to flourish today and could be respectively considered as community education. Looking back to the origins of philosophy in the fifth century $\mathrm{BC}$, the ancient Greek philosophers - particularly the Stoics, Epicureans, and Skeptics - clearly thought of philosophy as a form of therapy, which cured the toxic false beliefs that cause suffering. Similarly, Socrates suggested philosophy as a way of life, for better understanding, elaborating and managing one's emotions, and self, while learning through dialogue. Philosophers in the ancient world learned how to examine their beliefs through dialogue and conversation, and they lived in philosophical communities of shared values and shared practices.

Furthermore, it is important that training can occur wherever the trainees feel intimate. That could be in a library, an area of the municipality, a social center or, like in our case, in a school. This could be a key factor in achieving broader participation in adult education and in empowering the community. Finally, the role of the trainer is reciprocal, equal to the trainees, and authority is transferred to the learners while the educator becomes a collaborative learner. That is, they work in cooperation and in solidarity with each other. Moreover, these communities grow in the jungle of informal education, often hidden from the view of the state, universities, and other formal adult education providers. By 'informal', it is meant that learning is not publicly-funded, and is often organized and self-run by volunteers as in this case. Therefore, it cannot be planned or structured from the top-down. 
Dewey, in the early years of the 20th century, also insisted that philosophy should not be practiced within the "ivory tower" model of academic philosophy but instead, to stress the social and communal nature of learning (J. Dewey, 1910). Philosophy, he thought, should be a form of social practice that engaged with the social problems of the epoch. Additionally, he gave value to education that arises within social structures and contributes to them. His political ideal was of a 'Great Society', in which neighbors would meet up for face-to-face ethical and civic discussions - a vision of grassroots ethical philosophy that would inspire later community philosophers like Matthew Lipman. Lipman's concept of the "community of inquiry" was obviously influenced by American Pragmatist philosophers on one hand and Vygotsky's development psychology theories on the other (Lipman, 1991 $a, b)$. However, as Lipman suggested, the communities of inquiry should follow Socrates advice to "follow the argument wherever it leads" (Lipman, 1988). Moreover, recent research in $\mathrm{P} 4 \mathrm{C}$ sought to develop a form of $\mathrm{P} 4 \mathrm{C}$, which combines a Pragmatist with a virtue ethics approach (Lipman \& Sharp, 1994, Sprod, 2001).

A significant feature of community based education, as presented in this article, is having an open, rational discussion, whilst exploring and analyzing needs and expectations within the educational community. In a philosophical community inquiry inspired by Lipman's P4C, the discussion is directly related to values, ideas, and issues the participants face in everyday life, rather than conventional academic subjects. Moral and ethical issues and values of the trainees are stimulated by stories and are becoming the starting point. At the same time exploration, philosophical inquiry and discussion are the focus of the educational process.

\section{research methodology}

exploratory questions and goals

This research was organized to investigate the following hypothesis: 
I. If effective, parental-school cooperation can improve the academic and socioemotional performance of the pupil in the school as well as within the family environment.

II. While strengthening the philosophical dialogue in the community of parents in school, do we strengthen a meaningful dialogue among all members of the school community (pupils, teachers, parents, community)?

III. If the simultaneous reinforcement of reflection, critical thinking, and dialogue through the creation of philosophical communities with adults (parents) of diverse backgrounds can contribute to community empowerment and enhance the substantive discussion of all parties involved.

IV. Which areas, if any, of the educational process with the children can facilitate an organised training program for parents?

methodology

For the research presented, Action Research (AR) was chosen as described in the work of Kapachtsi \& Kakana (2010). AR is a form of thoughtful investigation that teachers and researchers use in planning, implementing, and evaluating. The intent is to improve school curricula, teaching practices, learning environments as well as their own professional development and understanding (Cohen, Manion \& Morrison, 2005, Rust, 2007). AR is carried out in real-life situations, has an empirical character, and includes reflective processes which allow enquiry, discussion and cooperation as an element of the research itself (Carr \& Kemmis, 1997, Christenson \& Sheridan, 2001).

It is considered to be qualitative research, which is based on the basic assumption that knowledge about humans is impossible without describing the human experience as it is encountered and as described by the protagonists themselves (Sachini-Kardasis, 2004). This type of research provides the possibility, 
through the recording of qualitative characteristics of the population under study, to certify data, which in a quantitative survey does not emerge (Iosifidis, 2003).

The particular AR was conceived in a school environment as a collaborative effort between the researcher-facilitator (teacher-psychologist, as a source of professional and scientific assistance), and of colleague- teachers and parents. It is characterized by spiraling cycles of problem identification, systematic data collection, interpreting, analyzing, and reflecting on a major theme (parents-school collaboration), data-driven action design, and activation, documenting and collecting data on performance, and finally, evaluating and disseminating the results.

As part of this process (AR), the following actions were achieved:

-Creation of focus groups among the teachers and the principal of the school (problematization, debate, reflection),

- Collection of information, either from international bibliography or diaries and memos from previous years,

- Determining the two diverse groups that would be explored: the Experimental Group (where the goal is to create a Community of Philosophical Inquiry) and the Control Group (where Epstein's Cooperation model is implemented, similarly with the previous years).

- Identifying, planning and implementing the main experimental activity (building a community of philosophical inquiry with the parents with the use of storytelling as stimuli for philosophical discussions),

- Designing and implementing simple exploratory questionnaires in the beginning and at the end of the school year with intent to initially explore the preconceived notions of the parents, mainly about school-family collaboration, and then come to an assessment at the end of the meetings in both school years and groups (eg. "Have you ever participated in any kind of parent's training?", "How often do you communicate with the school?", "What matters do you usually discuss with the teachers?" Etc). 
- Throughout the two years, there has been a participatory observation and recording of the actions (field notes, diary), in which teachers, parents and pupils have participated.

- Individual Student Portfolios (self-designed and based on the aims of the Greek national Curricula) have been documented by the teachers. Aiming on one hand to inform the parents during the individualized sessions throughout the year, and on the other hand, the Elementary School teachers' that would receive the students in the next year. The points that were addressed concerned the students' progress and their personal characteristics as observed (eg. Participation in class, social, emotional, and cognitive development, communication and problem-solving skills, etc.).

- The teacher modeled critical thinking and creative patterns of questioning and reasoning in the early stages to guide the adult-learners until the community of inquiry had been activated. The sessions were based on the same notion as with the children in the classroom, conceptualizing the construction of the zone of proximal development (Vygotsky, 1978) and thereby encouraging and advancing their individual learning.

Finally, the effects of the intervention were assessed to determine if improvement in communication and thinking skills had occurred. Indicators that can be identified and noted while building the philosophical community of parents were used for measuring its effectiveness (Wartenberg, 2014), (i.e. number of participants, levels in participation during sessions, questioning, reasoning and anticipation for the next meeting.)

- The results were discussed among the participants and their dissemination was planned.

sample $\mathcal{E}$ context 
More thoroughly, the situations and potentialities that have been enhanced are mentioned in this section. The empowerment of family relationships within school through AR has been implemented at the 1st Galatsi Kindergarten for two consecutive school years, 2014-15 and 2015-16. It is important to mention that compulsory education in Greece starts with one mandatory year of pre-primary (preschool) education. The specific school includes two full-day preschool departments. Each department has two teachers whom are responsible for working on a weekly shift rotation. One of the two sections played the role of the Experimental Group and the other had the role of the Control Group. Each is typically composed of 22-25 five to six-year-old children. This school is state-owned in a municipality near the centre of Athens and therefore pupils' parents are mainly of medium educational and economic profiles. At this school, the percentage of foreign families varies from 25\% to $40 \%$ over the last five years. In the first year of the research, there were 8 foreign children out of 22 enrolled. By the second year, the numbers changed slightly to 9 out of 23. Of those, all the children were already fluent Greek speakers.

Twenty parents (18 women, 2 men) participated in the program on a voluntary basis. Prior to their participation they had been informed about the content of the meetings/sessions from the specialized educator of their children's section (create a school for Parents in the form of a Community of Philosophical Inquiry). The majority (95\%) had never participated in any kind of parenting schools, in either individual or group meetings with a psychologist or other qualified staff in the past. The teachers of both departments, and in particular the ones from the Control group, were experienced in both teaching and parents' management. The collaboration between the teachers of the departments had always been successful in previous years, thus the students could follow a parallel educational program in each consecutive school year and with joint participation in pilot projects of the University of Athens, the Ministry of Education and other National Educational authorities. Nineteen out of the twenty parents who participated in the first year in the 
Experimental Group requested for the continuum of the group meetings in the following school year, despite their children moving on to the elementary school. As a result, the study of the Experimental Group 1 (parents of the 1rst Sch.Y.) could and did continue in the following year in parallel with the study of the Experimental Group 2 (parents of the 2nd Sch.Y).

During the first week of both school years, the teachers sustained a meeting with the parents, yet separately at each department. Its objective was to inform them about the basic functions of the school and the educational aims. Both Experimental Groups communicated with the teachers and consulted the principal, either as a group or individually, either in scheduled meetings or on demand. The principal in collaboration with the educational staff informed all parents from both Groups (Experimental \& Control) that the school had taken the initiative to adopt an innovative approach for collaborating with them to benefit the pupils. Then, as in previous years throughout the first month of student and parent adjustment, all parents of the school were supported and encouraged to join forces with educators to improve the school environment and enhance the feeling of community within a climate of high academic achievement. After the adjustment period, the group sessions of the Experimental Groups were taking place every 3 or 4 weeks. The activities were pre-planned in the context of creating a community of interactive and philosophical quests of mutual concern that emerged mainly from the exploratory questionnaire which was distributed the first two weeks of the school year. The areas of interest include: 1) child development, 2) feelings, 3) extracurricular activities and home study, 4) communication, 5) limits and rules, 6) social networking and globalization, 7) multiculturalism and pluralism of religions as a new reality, 8) diversity, 9) ecology, 10) human rights, 11) sexual education.

At the aforementioned questionnaire that was distributed, they could, among other things, propose topics of discussion that would be of their interest. At the end of each school year, another questionnaire helped the evaluation of the project from 
the participants themselves. The teachers held individual sessions for further communication with the families, at a designated time, in the kindergarten, while considering the working hours of the parents.

The regular informative group and individual meetings of teachers with all parents, for both departments, had taken place at least four times cumulatively during the school year and always in the afternoon hours, pursuing parents' participation in school activities. During those meetings, teachers presented to parents their child's progress and any concerns in all areas of learning, especially social and emotional.

Conclusively, during this exploratory effort to engage parents in their children's educational framework (home and school), the researcher has used carefully designed activities. That is: a) afternoon or morning, individual and group meetings with parents, $b$ ) engagement of parents into the philosophical inquiry while in groups, and through short stories to trigger philosophical questions; c) distribution/posting of scientific articles (relevant to the session subject-matters), d) playful home-learning activities were suggested and discussed d) Evaluation Feedback.

Additionally, the stories that were used were selected by the facilitator as a result of their emerging philosophical ideas and their particular genre that was anticipated to trigger all ages. The specific stories had been read previously and stimulated questions and discussions for the preschool students. The participation in the procedures explained above has been carried out with the consent of all of the participants, while at the same time maintaining their anonymity wherever this was deemed necessary.

\section{limitations}

This research has used a small, non-representative sample and therefore the results cannot be generalized to a broader population. 
results

The research presented has been motivated by a working hypothesis based on literature findings and on the observation of the potentialities emerging from the educational context in previous years. All the following results were based on continual evaluations by all parts involved. In particular, the outcomes from the Experimental Group unfolded to a considerably greater extent compared to the Control Groups'. The appearance of certain attitudes was either not apparent before or with a very low progression compared to previous years. Actual comments and essays from participants are attached at the end of the article.

- Immediateness in acquiring image for the family $\mathcal{E}$ cultural environment of the students $\mathcal{E}$ thus better facilitating the educational process. While discussing subjects such as religion, culture, education, rules and others, the facilitator collected personal information about each family (in field notes). This information was used to personalize teaching directly, according to individual and family traits. One such example involves a student whose dad had died during that year. Through the philosophical discussion about "death", the facilitator discovered that the specific child was raised mainly by the father because the mother initially had refused to have another child (she had already single-handedly raised her own 16-year-old twin girls). The boy had a very strong bond with the father and his sisters but was only slightly attached to the mother and therefore required a more personalized approach in the classroom.

- Empowering parents to develop effective parenting strategies. After having philosophically discussed "parenthood" in a meeting, a great need for information and suggestions about parenting strategies had emerged. Scientific articles and suggestions were given to all the families in school, however those who actually applied the strategies and gave feedback were the ones from the experimental groups. 
- Cultivating group climate for the young $\mathcal{E}$ adult students. The parents from both Experimental groups soon established close ties among each other in both years. As a result, they presented great willingness to volunteer at school to do anything they were asked to. Additionally, out-of-school meetings occurred much more frequently for the experimental group. Their children also attached much faster and formulated a team, compared to previous years or to the other department.

- Integration of parents into the educational process inside and outside the school. As mentioned above, parents were very often willing to take part in school activities and school trips, and often asked for advice on playful educational activities that could take place outside of the school setting. Their interest in the social and emotional maturity of their child grew significantly while they stopped wondering if their child would learn how to read and write by the end of the year.

- Develop trust relationships in the Educational Triangle: School - Child - Parent. Discussion among parents and teachers increased significantly, and not just in regards to their children's performance at school (as mentioned in the questionnaire by all parents). After the 2 nd or 3rd session, the majority of parents would bring up a variety of matters for critical and creative discussion. In addition, they would soon pursue further contact with the teachers or other parents to discuss their personal issues, sometimes looking for advice on issues that concerned their family and not just their children. In one case, a mother in the study shared information regarding problems with her husband (he had just lost his job). Another mother shared that she was continuously fighting with her mother, with whom she shared the same apartment, and was looking for an excuse to move elsewhere with her husband and children. Teachers were also eagerly discussing their concerns with the parents about their children, or were asking them for help, without hesitation. The children seemed to enjoy this relationship and often told their parents in the mornings, "leave now, this is my teacher", and the parent responded with satisfaction, "but she is my teacher too, you know!" 
- Developing a positive climate in school from all participating sides.

All issues were resolved in a positive manner even when the person concerned (parent, teacher) did not achieve the goal e.g. damage at school that was not repaired directly. The discussion that concerned several issues evolved to a "caring" level compared to the previous "complaining" one.

- Parents promoted their children academically after assimilating how to enhance and link learning in the family environment with learning at school. As documented in the short essays included with the evaluation forms, all of the participants asserted or mentioned a dramatic change in both, their own and their child's way of discussing or reflecting on various issues. Many of them declared raising questions "like children" and discussing issues philosophically that were stimulated by current events or by a particular incident during their day. Most participants shared that the subjects discussed at home were now not just about academic performance but mostly about friendship, peace, inclusion, being different, death, happiness etc.

- Parents responded with great enthusiasm to school whenever cooperation was sought. The parents were eager to help the teachers in every situation, by painting walls, cooking, accompanying students at out-door activities, making whatever needed for the bazaars etc.

- The relationships between the parents that participated persevered in the following years. The parents from the Experimental groups set up a group in an application in order to be able to communicate daily. There was a case in which a father was seriously injured by a car and the rest of the team supported the mother and the children for at least four months (cooking, cleaning, baby-sitting). In another case, a mother had to go abroad for a serious surgery and the group, in addition to the psychological support they provided daily with their discussions raised money for the patient's expenses. Moreover, a mom from the group accompanied the patient to the country where the surgery took place because she knew the language. More recently, a mom said "I cannot remember my life before you." and another stated that 
"while looking at my wedding pictures, a few days ago, I was trying to find you all..because I feel like I've known you forever".

- The parents who participated were looking for cooperation and remained attached to the kindergarten during the next year, regardless of having their children in elementary school. They actually said: "We want to follow this community of parents next year too. if you cannot make a 2nd group with us, we will hide behind the doors and windows to listen to the stories for your new group and participate...". The parents from both Experimental groups still participate in raising funds for the school i.e. through organizing the Christmas and Easter Bazaars.

The last of the results, but certainly not the least important, were derived unexpectedly from the teachers. That is, recognizing and highlighting the contribution of the family environment to children's psychology, its relationships with the peer group, and the educational process. The three teachers, except for the researcher/observer, were constantly discussing and enjoying the active participation of parents as well as the development of an integrated community. Meanwhile, the pupils, teachers and parents worked together for the benefit of the children's and school's community. Additionally, there was one parent from the Control Group who requested to be included in the meetings of the Experimental Group (School for Parents- as called) because, as she explained to the teachers, "could not resist the wonderful feeling of community, that emerged from that particular group of parents inside and outside the school!!"

Most importantly, this relationship was built despite any SES, linguistic, religious, and academic background differences. The Experimental group parents' relationship with the teachers is still very strong and continues to evolve. This is likely due to the fact that all participants had the opportunity to build personal, earnest connections among one another.

\section{conclusions}


For years, both parents and teachers have faced the challenge of preparing a new generation of people in parallel, and not in cooperation with each other. However, in order to achieve cooperation between the institutions of school and family, their communication should be essential and not formal. The need for communication and intensified relationships for the children and their parents has been revealed through this collaboration. There seems to be no other alternative than teamwork, respect for diversity and willingness by all those involved in the pedagogical process.

It seems that in this case such an alliance has been successful in various ways, as mentioned in the results. The great need for effective school-family cooperation with the primary aim of maximizing the pupil's benefit for its full-fledged development is disclosed. While at the same time, parents come to understand the sincere concern of teachers for their students. In addition, what has been realized is that both teachers and parents are required to work collectively as partners in favor of their children's education. Furthermore, they should work together to identify the significant contribution of both sides as it relates to the development and success of the children. It has also been verified that effective family-school collaboration, based on mutual respect and trust, promotes parental empowerment through positive, meaningful, two-way communication between school and home. Moreover, while educators are seeking cooperation with parents, they need also to acknowledge them as the first teachers of their children and be flexible and innovative in their efforts to reach out to a diverse, modern society.

An important issue that has been verified is that cooperation should and could be open while ensuring that opportunities for participation for all the families are made available, regardless of the educational level of the parents, their linguistic background, and/or their familiarity with the school processes. However, in order to achieve such unanimity, we likely need to strengthen these skills among all three parts of this alliance (students, teachers, and parents). Thus augmenting life, cognitive 
and learning skills that are valuable when aiming to build a community of individuals whom have the ability to react, adapt, and enact change. Obviously, skills such as critical thinking, reasoning, communication, and collaboration are crucial for the students (Lipman, \& Sharp, 1994). Nevertheless, how about nurturing them respectively for teachers and parents, who are mainly interacting in the immediate environment of the students? If children could communicate, interact and learn in respective ways within home and school environment, the impact would possibly be more intense. Consequently, parents and teachers require a considerable amount of appropriate scientific support and training. This exploratory effort, with a relatively small number of parents, has shown that with appropriate guidance a "newborn" philosophical community can have impressive effects, not only in communication, but also in the relationships of all members of the micro-system (Bronfenbrenner, 1992) therefore fostering advancement of the children.

In other words, this project emphasizes the necessity for a multifaceted intervention-empowerment of the educational and learning process with alternative strategies by both teachers and parents. Moreover, it seems important to design the support strategies for parents, while respecting and taking into consideration parents' experiences and resources. Another important issue that arises through this effort is the need for parents to discuss their concerns about their children in the past, present, and future, while at the same time listening and exchanging thoughts with other parents about their respective experiences and difficulties. This chance for discussing matters of mutual concern was given through the philosophical community. Consequently, children and those involved in the pedagogical process are collecting short-, medium- and long-term results throughout parent / child / teacher interaction and communication skills enrichment. Furthermore, children can create solid foundations for their school success in virtue of the improved family relationships. The above proposal is, in my opinion, a minimal step in the right direction so that parents and educators develop effective strategies for dialogue and 
cooperation in order to create a two-way communication between home and school. In addition, it provides an opportunity for the disclosure of "authenticity, in the education of children". Teachers, in turn, within a society dominated by social, cultural, and linguistic diversity, are now more than ever, obliged to communicate with all families through innovative and flexible methods that can promote and enrich the students and their families. By actively discussing and participating, parents learn ways to facilitate the development of the academic and social skills of their children to their fullest potential. Conclusively, this project attested that a school community that works to increase organic and sincere dialogue between parents, teachers and students can create a new, stronger community where parents and school become partners and co-conductors in the upbringing and education of their children.

\section{appendix}

parents' actual comments in the evaluation questionnaires \& essays written a year later:

1)"Raising questions dragged me out of my misery because it makes me feel like a child!!"

2) "Having a philosophical discussion about Peace for example, helped my self-confidence because I felt important!"

3)"In my life, whenever I spoke, even when ordering a loaf of bread in a bakery, I was becoming red. Now, after the sessions, I can express anything, really anything I think!!"

4) "It was like we were doing it for years. Right from the first day - session we started thinking -out loud, raising questions, problematizing, reflecting, we matured!! We became a community and very soon we realized that we could offer to our school and even more to our children. We were happy and our children were happy as well!!",

5)"I look forward to for the next time and while being there I felt like every cell in my body was seizing every word, every single moment!"

6) "None of us could ever imagine that something so simple as a philosophical discussion could change our lives!"

7) "My participation at parents' school, started relatively timidly. Even though I am quite shy and perhaps close -minded in such initiatives, I felt captured by curiosity about what would follow since I had never had or even heard about such an attempt before. 
parents' philosophical community: when parents go to school!

The teacher, while watching her the whole year before - my eldest daughter went to different department at the same school-I did not know her. I had always been polite but lacking self-confidence. I would just leave my children at school, go to work and did not have any kind of relationship with other parents. I was focused only on my work and my family quite lacking self-confidence but perhaps with a deep need to join a community and offer to the others.

That's how the "parents' school" started ... with a fairy tale - I cannot remember the exact title, perhaps I am getting old, but there are so many things that followed! However, it was enough for a first deep breath! The teacher touched our soul, got into our minds, in our family, our home and our hearts. And we started to open up, to think in a serious manner about issues that I did not care for before. We started reflecting on others' thoughts without judging or trying to dominate over others. We also started discussing the ways we think and argue with others, wonder and question ourselves about a variety of important subjects while having a touch of joy and happiness. We matured. We transformed. We learned to solve our problems with our children, with our companions and between us differently. We have learned to look at them differently.

We were involved in children's school activities and we were excited about it because we were able to offer to our school community and to our children so much more. We were happy and children were also enjoying our happiness with us!

From the point of being locked in my microcosmos, I found another world where I could have a purpose, where I could offer and be a part of a community. Very soon, I felt like I had found the ultimate purpose of life that could lead me to completion.

Our meetings as a group continued for a second year and we would certainly continue for a third but our teachers had to leave us, she was moving to another country... we felt like a drop in the ocean!!!! And yet this act was another lesson for us. It has been a lesson of determination, power of love, fearless for the unknown, the commitment to the family and a proof that we still have a long way to go...

Even though we were left behind, the Phil-girls got even closer and hold tight on a great friendship. We kept meeting often, inquiring, sharing and co-constructing our thoughts, whenever possible and always holding each other's hand.

Without our Teacher's initiative for the parents' school, we would not have any of that. We feel very lucky for being able to build such a community where we could pursue ourselves, question our ethics and morality and keep doing it after three years. ... this constant effort to reach our ideal self ... And I'm sure we will persist on doing it for many many years ...!!!"

8) "PARENT SCHOOL: A Sweet Story

The participation in the parents' school was done "automatically". One of the teachers suggested it and the parents just accepted it! It was like we were looking for it..

But none of us could imagine that something so simple could change our life.

Personally, I was looking forward for every meeting while during the sessions I felt that all my cells were seizing every moment, every minute. After a few meetings, I realized that perhaps all of us felt the same way. 
It is not just all that I have learned, it is the way and the process. Through the love, training and experience of the teacher and the different personalities of all the participants I entered the process of actual self-criticism and self-awareness in order to become a better person and a better mother and wife. I learned how to listen actively and discuss. How to understand my family, and myself, I learned ways to volunteer and to share and even, enjoy it. Above all, I found out ways to understand and discuss with my children.

When the year was over, and while I had gained new friends, none of us could accept that the parents' school was over. Therefore, we followed our Teacher informally wherever she could meet us and we never stopped taking advantage of the inexhaustible source of love, support, and learning that she provided. Later on she managed to give us the chance to continue for a 2 nd year, even though our children were no longer students at her school.

It has been three years and we are getting more intimate each day. We have had our teacher initially to guide us, but after a while, we have had one another and we still do. Without any criticism, malice, doubts, but only with love, respect, simplicity and humor we know that at any moment there is someone who will listen to you, support you, make you laugh and cry with you.

The parents' school is for me something sweet and necessary in my life. I am sure that when my child grows up and marries, in the church among the guests will be his companions from kindergarten, his teacher and all the "Phil- Girls"!!!

Yours,

T. P.

A proud member of the Parents' School"

9) "Lately, that I have a little time, I often think of you and think about our parents' school. I do not know what it was like before. I so much wanted to be in the discussions. I was looking forward to meeting and hearing you talk. I kept listening and admired you whenever you were talking. Moreover, I was getting a thousand pulses, blush, and hoped that you would not turn to me, would not ask me to talk. I still remember those embarrassing moments when I started expressing my thoughts.. I was anticipating every meeting to meet you, reflect with the others, and go back home full of thoughts and emotions. It took me about six-seven months to start talking, to express myself. Watch me now how I talk, react, reflect, and discuss every kind of issue. You have seen me being transformed to the person I was dreaming to be. Not to mention the fact that I have acquired friends I want to spend time with and accept me as I truly am."

10) "Four years later we are still so close to one another, our group has become self-directed. When our Teacher had to leave us, she kept sending us triggers online (short texts) for a couple of years. Now we find our own for our philosophical discussions..! We still keep the same rules; we all know when it is time to discuss philosophically and when we need to discuss personal matters. We do know and understand the difference, but we also know that we need both ways. Each one of us helps each other in a different way!" 


\section{bibliography}

Anfara, V. A., Jr. \& Mertens, S. B. (Eds.). (2008). Varieties of Parental Involvement. Middle School Journal, 39(3), 58-64. Retrieved from: <http:/ / www.amle.org/Publications/MiddleSchoolJournal/Articles>

Aronson, J. Z. (1996). How schools can recruit hard-to-reach parents. Educational Leadership, 53(7), 58-60.

Bali, Demo \& Wedman. (1998). Family involvement with children's homework: An intervention in the middle grades. Family Relations. 47(2), 149-157.

Bandura, A. (1977). Social Learning Theory. Eglewood cliffs, NJ: Prentice Hall.

Becker, H. J., \& Epstein, J. L. (1982). Parent Involvement: A Survey of Teacher Practices. The Elementary School Journal, 83(2), 85-102.

Bradley, R. H., Caldwell, B. M., \& Rock, S. L. (1988). Home environment and school performance: A ten-year follow-up and examination of three models of environmental action. Child Development, 59, 852-867.

Bronfenbrenner, U. (1979). The Ecology of Human Development. Cambridge, Harvard University Press.

Bronfenbrenner, U. (1992). Ecological systems theory (p. 187-249). In R. Vasta (Ed.), Six theories of child development: Revised formulations and current issues. London: Jessica Kingsley Publishers.

Brookfield, S. (1983) Adult Learners, Adult Education and the Community. Milton Keynes: Open University Press.

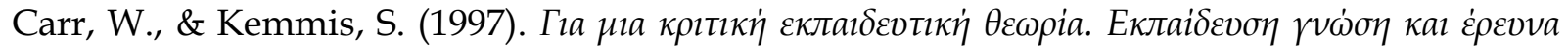

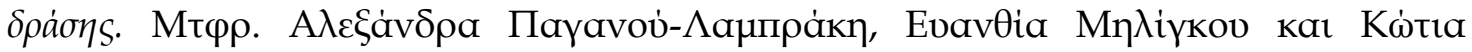

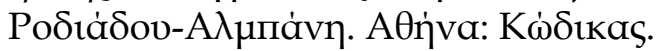

Carasquillo \& London. (1993). Parents and schools: A source book. New York: Garland.

Chavkin, N., \& Williams, D. (1987). Enhancing parent involvement: Guidelines for access to an important resource for school administrators. Education and Urban Society, 19, 164184.

Cristenson, N., \& Sheridan, S. (2001). Schools and Families: Creating Essential Connections for Learning. New York: The Guilford Press.

Cohen, L., Manion, L., \& Morrison, K. (2005). Research Methods in Education (5th edition). London \& New York: Routledge.

Comer, J. P. (2005). The rewards of parent participation. Learning from urban schools Journal. 62(6), 38-42.

Connolly, B. (2005). Learning from the Women's Community Education Movement in Ireland; In J. Crowther, V. Galloway \& I. Martin (Eds.), Popular Education: Engaging the Academy, Leicester: NIACE.

Dewey, J. (1910). Systematic Inference: Induction and Deduction; In J. Dewey, How we think (pp. 79-100). Lexington, MA, US: D C Heath.

Eccles, J., \& Harold, R. (1996). Family involvement in children's and adolescent's schooling. In A. Booth \& J. Dunn (Eds.), Family-school links: How do they affect educational outcomes. 3-34. Mahwah, NJ: Lawrence Erlbaum Associates.

Epstein, J. L. (1982). Student reactions to teacher practices of parent involvement. Paper presented at the annual meeting of the American Educational Research Association. 
Epstein, J. L. (1987). Toward a theory of family-school connections: Teacher practices and parent involvement. In Hurrelman K, Kaufmann FX, Sel FL. (Eds.), Social intervention: Potential and constraints. (pp. 121-136) Berlin: Walter de Gruyer.

Epstein, J. L. (1985). Home and school connections in schools of the future: Implications of research on parent involvement. Peabody Journal of Education, 62(2), 18-41.

Epstein, J. L. (2001). School, family and community partnerships: Preparing educators and improving schools. Boulder, CO: Westview Press.

Epstein, J. L. (2005). School-initiated family and community partnerships. In T. Erb (Ed.), This we believe in action: Implementing successful middle level schools. (pp. 77-96) Westerville, $\mathrm{OH}$ : National Middle School Association.

Epstein, J. L., Sanders, M. G., Simon, B. S., Salinas, K. C., Jansorn, N. R., \& Van Voorhis, F. L. (2002). School, community, and community partnerships: Your handbook for action (2nd ed.). Thousand Oaks, CA: Corwin Press.

Fan, X., \& Chen, M. (2001). Parental Involvement and Students' Academic Achievement: A Meta-Analysis. Educational Psychology Review. 13(1), 1-22.

Greenwood, G. E., \& Hickman, C. W. (1991). Research and practice in parent involvement: Implications for teacher education. The Elementary School Journal, 19(3), 281-287.

Griffith, (1996). Relationship of parental involvement, empowerment and school traits to students' academic achievement. Journal of educational Research. 90(1), 33-41.

Henderson, A. (1987). The evidence continues to grow: Parent involvement improves student achievement. Columbia, MD: National Committee for Citizens in Education.

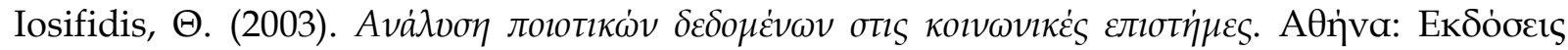
Kрıtткं.

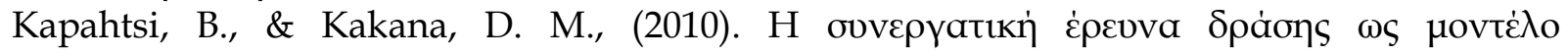

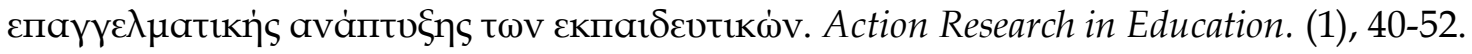

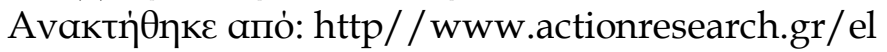

Keyes, C. R. (2002). A way of thinking about parent/teacher partnerships for teachers. International Journal of Early Years Education, 10(3), 177-191.

Lipman, M. (1988). Philosophy goes to school. Philadelphia: Temple University Press.

Lipman, M. (1991a). Thinking in Education. Cambridge, MA: Cambridge University Press.

Lipman, M. (1991b). Rediscovering the Vygotsky Trail. Inquiry, 7(2), 14-16.

Lipman, M., Sharp, A. M. (1994). Growing up with Philosophy. Dubuque, Iowa, Kendall Hunt Publishing Company.

Martin, J., Ranson, S., \& Tall, G. (1997). Parents as partners in assuring the quality of schools. Scottish Education Review, 29(1), 39-55.

Moles (1993). Collaboration between schools and disadvantaged parents: Obstacles and Opennings. In N.F. Chankin (Ed.) Families and schools in a pluralistic society. (pp. 21-49). Albany: State University of New York.

National PTA, (1997). National Standards for Parent/Family Involvement Programs. Chicago, Ill, ERIC NUMBER: ED 405405.

Neile, C. S. (2009). Storytelling and Social Change: Introduction to the Special Issue. Storytelling, Self, Society. 5(2), 69-71.

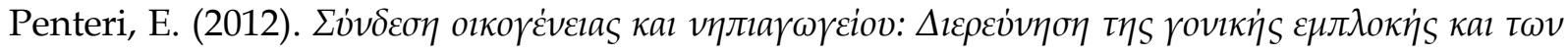

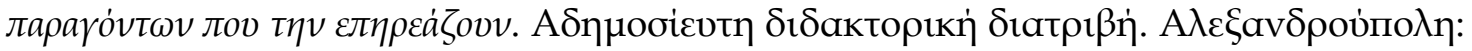
Т.Е.Е.П.Н.- $\Delta \Pi \Theta$. 
parents' philosophical community: when parents go to school!

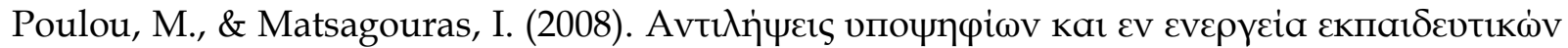

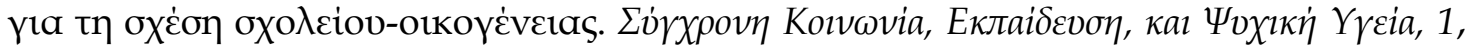
23-53.

Raffaelle, L., \& Knoff, M. (1999). Improving home-school collaboration with parents of children at risk: Organizational principles, perspectives and approaches. School psychology Review, 28, 448-466.

Rust, F. O'C. (2007). Action Research in Early Childhood Contexts. In J. A. Hatch (ed.), Early Childhood Qualitative Research. (pp. 95-108). New York: Routledge.

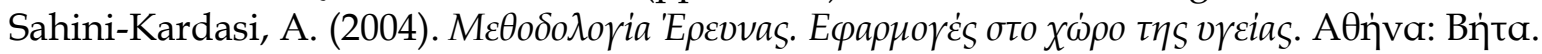

Sprod, T. (2001). Philosophical Discussion in Moral Education: The Community of Ethical Inquiry. London: Routledge.

Steinberg, L., \& Silk, X. (2002). Parenting adolescents. In Bornstein, M. H. (Ed.), Handbook of Parenting: Vol. 1: Children and Parenting. (pp. 103-133). Erlbaum, Mahwah, NJ.

Vygotski L.S. (1978), Mind in Society. Cambridge (MA.), Harvard University Press.

Vincent, C. (2000). Including parents? Education, citizenship and parental agency. Open University Press.

Wartenberg, T. E. (2014). Assessing an elementary school philosophy program. Thinking: The Journal of Philosophy for Children 20(3-4), 90-94.

received in: 10.12 .2018

aproved in: 03.08.2019 